\title{
The Effect of DER, EPS, and Underwriter Reputation on Initial Return with Interest Rate
}

\author{
Lasamanah ${ }^{1, *}$ Disman $^{2,}$ Nugraha $^{3}$
}

\author{
${ }^{1}$ Universitas Pendidikan Indonesia \\ ${ }^{2}$ Universitas Pendidikan Indonesia \\ ${ }^{3}$ Universitas Pendidikan Indonesia \\ *Corresponding author. Email: felastz@gmail.com
}

\begin{abstract}
This study aims to analyze the effect of EPS, DER, and underwriter reputation on initial returns, which is moderated by the interest rate on IPO issuers. Statistical data analysis is logit regression analysis. The results showed that EPS, DER, and underwriter reputation, which were moderated by the interest rates, significantly influenced the initial return. The testing of each variable's hypothesis showed that DER and underwriter reputation influenced the initial return significantly. On the contrary, EPS and interest rates affected initial returns significantly. The DER and underwriter reputation, which are moderated by the interest rate $(\mathrm{SB})$ indicated that the DER* SB and the reputation of the underwriter* SB had no significant effect on the initial return. As for the variable EPS* SB indicated that it had a significant effect on the initial return. This means that the EPS affected the initial return with the interest rate strengthening the relationship between EPS and initial return.
\end{abstract}

Keywords: IPO, DER, EPS, Underwriter Reputation, Initial Return, Interest.

\section{INTRODUCTION}

Initial Public Offering (IPO) is a corporate action carried out by the company in shaping its stock price so that its value can be measured. Many investors got very high profits when making an IPO. Only, unfortunately, this IPO moment is often used by some large investors or institutions to speculate. This was stated that in the IPO event, many investors were used to carrying out actions to fry shares. This, in the long run, will endanger the capital market because the fundamentals are not suitable for investment. This condition is caused because many Indonesian investors follow the trend of investing instead of looking at the company's fundamental factors. Investor behavior like this will impact other investors who go along (herding behavior) without doing a fundamental analysis of the shares to be bought. This social interaction can affect investors' decisions in making transactions [1].

Furthermore, according to [2], investors in Indonesia are believed to still not make full use of financial information that has been published in their investment decision-making because it is believed that most Indonesian investors are speculative investors who have more funds without being accompanied by knowledge and skills in investing. The investor's behavior causes the prospectus not to be used by investors to make an investment judgment. This is consistent with [3] study, which states that accounting information is not useful in making decisions because the information signals in financial statements cannot make investors changes to previously held beliefs. This contrasts with the signaling theory. According to [4], the company's signal is an action taken by the company's management that provides instructions for investors about how the management views the company's prospects. An IPO company's prospect can be seen from the prospectus issued by the company, specifically financial information.

One financial information is the level of DER (Debt to Equity Ratio). DER is a fundamental aspect that investors should consider in investing. In general, investors need to be aware of companies with high DER and continue to increase from time to time because the amount of loans that are too large causes the company's financial risk to increase, so the company is at risk of bankruptcy. If the company is truly declared bankrupt, it can be expected to face the threat of forced delisting from 
the Indonesia Stock Exchange [5]. Therefore, DER should be considered by investors in conducting research.

Another financial performance that investors must consider is EPS. EPS is income that shareholders can receive. EPS can be used to predict stock price movements and possible dividend values to be received by investors. Knowing the value of EPS allows shareholders to make profits directly without selling their shares [6].

Non-financial performance in carrying out an IPO is the selection of a reputable underwriter. Underwriter as an underwriter is a party that bridges the desires of the company and investors. The underwriter, together with the company, determines the initial price of the company conducting the IPO. The underwriter's role is to convince local and foreign investors to be willing to buy the company's shares, so the role of the underwriter in implementing the IPO is crucial and strategic. Underwriters' achievements can be judged by enthusiastic investor responses and premium pricing [7]. Investors consider underwriters as certifiers of share prices of issuers to have information, so when a company submits information, it will be responded to by the market as a signal of certain events that can affect the company's value [8].

Another aspect that affects investors investing in company shares is the benchmark interest rate. Interest rates affect the money market and the stock market because they will grow and provide monetary stimulus if Indonesian Bank can reduce interest rates. This reduction in interest rates will make the prospect of issuers more attractive. Besides, the interest rate is a ballast for the IHSG. IHSG is an indicator of the performance of a stock market. Therefore, according to [9] that investors must invest in shares in a manner incrementally when interest rates change. The research results conducted by [10] show that economic conditions had a significant effect on the initial return. Economic conditions can increase or decrease the returns to be received by investors. This is because the macroeconomic situation will determine whether the exchange situation is bullish or bearish. The interest rate is a factor that investors consider when investing. Thus what distinguishes this study from other studies is the interest rate used as a moderating variable that can strengthen or weaken the effect of DER, EPS, underwriter reputation on initial return.

Based on the phenomena and the results of the research above, there are inconsistencies in the study results, so that DER, EPS, and underwriter reputation are still needed to research about initial returns to be obtained by investors. Thus the purpose of this study is to analyze the effect of DER, EPS, and underwriter's reputation on initial returns that are moderated by interest rates.

Many authors studied the effect of DER, EPS, underwriter reputation, the interest rate on initial return.
The criteria for affecting DER, EPS, underwriter reputation, the interest rate on initial return are signaling theory.

Several studies conducted by [10] show that DER affects the initial return. Then research [11] says that DER harmed One financial information is the level of DER (Debt to Equity Ratio). DER is a fundamental aspect that investors should consider in investing. In general, investors need to be aware of companies with high DER and continue to increase from time to time because the amount of loans that are too large causes the company's financial risk to increase, so the company is at risk of bankruptcy. If the company is truly declared bankrupt, it can be expected to face the threat of forced delisting from the Indonesia Stock Exchange [5]. Therefore, DER should be considered by investors in conducting research. Several studies conducted by [11] show that DER affects the initial return. Then [10] that DER had a negative effect on initial return. Research by [12] and [13] shows that DER had a significant effect.

Meanwhile, [4] show that DER had influenced to initial return. This study is in line with [15] that DER was no effect on underpricing. Furthermore, [16] shows that DER did not affect initial return, so does [17] that DER had no effect on initial return. Research [14] that DER did not affect the initial return. Research by [12] and [13] shows that DER had a significant effect. Meanwhile, [14] show that DER was an influence on initial return. This study is in line with [15] that DER was no effect on underpricing. Furthermore, [18] shows that DER did not affect initial return, so does [11] says that DER had no effect on initial return. Research [14] that DER did not affect the initial return.

Another financial performance that investors must consider is EPS. EPS is income that can be received by shareholders. EPS can be used to predict stock price movements and possible dividend values to be received by investors. Knowing the value of EPS allows shareholders to make profits directly without having to sell their shares [6]. Several studies relating to EPS on core returns were carried out by [10] that EPS shows factors that negatively affected initial returns. Then [19] research shows that EPS affected underpricing. Furthermore, [20] show that EPS affected the return of 1 day, 1 month, and 1 year after the IPO. Whereas [21] research shows that EPS was not significantly affecting initial stock returns. Then [22] shows that EPS had no significant effect on initial return. Furthermore, [23] states that EPS had no affected on initial return. Reference [24] shows that EPS did not affect the initial return. Feference [25] showing that EPS had no affected initial return.

Non-financial performance in carrying out an IPO is the selection of a reputable underwriter. Underwriter as an underwriter is a party that bridges the desires of the company and investors. The underwriter, together with 
the company, determines the initial price of the company conducting the IPO. The underwriter's role is to convince local and foreign investors to be willing to buy the company's shares, so the role of the underwriter in implementing the IPO is critical and strategic. Underwriters' achievements can be judged by enthusiastic investor responses and premium pricing [7]. Investors consider underwriters as certifiers of share prices of issuers to have information, so when a company submits information, it will be responded to by the market as a signal of certain events that can affect the company's value [8]. Several studies have shown that the underwriter's reputation positively affects initial returns [26]. Then [27] research shows that underwriters' reputation has minimal effect on initial returns. Reference [28] states that the underwriter's reputation has a negative effect.

Furthermore, [13] states that the underwriter's reputation significantly affects initial return. According to [29], that underwriter's reputation effectively increases initial return. According to [22] that the Underwriter's Reputation has a significant effect on initial return. In contrary to research by [24], it shows that the underwriter's reputation did not affect the initial return. Furthermore, [30] showed that underwriter reputation had no significantly affected the initial return. Later research [31] showed that the reputation of the underwriter was not proven to affect the initial return. [32], the underwriter's reputation had not influenced initial return.

Another aspect that affects investors investing in company shares is the benchmark interest rate. Interest rates affect the money market and the stock market because they will grow and provide monetary stimulus if Indonesian Bank can reduce interest rates. This reduction in interest rates will make the prospect of issuers more attractive. Besides, the interest rate is a ballast for the IHSG. IHSG is an indicator of the performance of a stock market. Therefore, according to [9] that investors must invest in shares in a manner incrementally when interest rates change. The research results conducted by [10] show that economic conditions had a significant effect on the initial return. Economic conditions can increase or decrease the returns to be received by investors. This is because the macroeconomic situation will determine whether the exchange situation is bullish or bearish. The interest rate is a factor that investors consider when investing. Thus what distinguishes this study from other studies is the interest rate used as a moderating variable that can strengthen or weaken the effect of DER, EPS, underwriter reputation on initial return.

\section{METHODS}

The type used in this research is explanatory research, which explains the causal relationship between variables through hypothesis testing [33]. The data used as a basis for testing hypotheses are secondary data obtained from the company's prospectus. Table 1 . Show the research variables that are objects in this study.

Table 1. Operationalization of Variables

\begin{tabular}{|l|l|}
\hline \multicolumn{1}{|c|}{ Variables } & \multicolumn{1}{|c|}{ Description } \\
\hline Debt to Equity Ratio & $\begin{array}{l}\text { Debt to equity ratio owned by } \\
\text { the company. DER } \\
\text { measurement used the value of } \\
\text { DER [12], }\end{array}$ \\
\hline Earning Per Share (EPS) & $\begin{array}{l}\text { Earnings per share describe the } \\
\text { amount of rupiah obtained for } \\
\text { each share of common stock or } \\
\text { net income per sheet of common } \\
\text { stock. Measured by the value of } \\
\text { EPS [28]. }\end{array}$ \\
\hline Underwriter Reputation & $\begin{array}{l}\text { An Underwriter is a supporting } \\
\text { institution that plays a } \\
\text { significant role in the going } \\
\text { public issuers. Measured using } \\
\text { variable categories where the } \\
\text { value of 1 for underwriters is in } \\
\text { repute and the value of 0 for } \\
\text { underwriters who are not } \\
\text { reputed [34]. }\end{array}$ \\
\hline Interest Rate & $\begin{array}{l}\text { The Abnormal return is the } \\
\text { difference in return that occurs } \\
\text { with expected returns. [35] } \\
\text { Measured by the level of } \\
\text { positive initial returns } \\
\text { categorized underpricing = an } \\
\text { initial negative or zero returns } \\
\text { categorized as non- } \\
\text { Underpricing = 0 }\end{array}$ \\
\hline Initial Return & $\begin{array}{l}\text { Represents the real interest rate } \\
\text { set by the central bank with the } \\
\text { monthly SBI interest rate [36] }\end{array}$ \\
\hline
\end{tabular}

The population in this study was companies that conducted IPOs during 2007 - 2017, as many as 247 companies. Some companies do not have complete data from the existing population so that from 247 companies can only be taken as a sample of 209 companies. Thus the sampling method uses purposive sampling. To test the effect of DER, EPS, underwriter's reputation on initial return with moderating variable interest rates using logit regression, with the following model equation (1):

$$
\begin{aligned}
& \ln \left(\frac{\hat{\mathrm{p}}}{1-\hat{\mathrm{p}}}\right) \Delta I P_{\imath}=\beta_{0}+\beta_{2} \Delta \mathrm{EP}_{\imath}+\beta_{2} \mathrm{E} \Pi \Sigma_{\imath}+\beta_{3} \mathrm{P} \varepsilon \pi_{-} \mathrm{Y} v \\
& \delta \varepsilon \rho_{\imath}+\beta_{4} \Sigma \mathrm{B}_{\imath}+\beta_{5} \Delta \mathrm{EP}_{\imath} * \Sigma \mathrm{B}+\beta_{6} \mathrm{E} \Pi \Sigma_{\imath} * \Sigma \mathrm{B}+\beta_{7} \mathrm{P} \varepsilon \pi_{-} \mathrm{Y} v \\
& \delta \varepsilon \rho_{\imath} * \Sigma \mathrm{B}+v_{\iota}
\end{aligned}
$$

Several analytical tests performed are data normality tests using the Jarque-Bera coefficient (J-B) to obtain accurate results. Then the classic assumption test consists of a multicollinearity test with a Pairwise Correlation value $>0.8$, a heteroscedasticity test measured using the $\mathrm{ARCH}$ test with Prob Obs * R_squared>0.05, and autocorrelation test using LM (Bruesch Godfrey method) with Prob value $\mathrm{Obs} * \mathrm{R} \_$squared $>0.05$. To see the suitability of the likelihood ratio model using logit regression with interpretation using Odd Ratio. The magnitude of the independent variable's contribution to 
the dependent variable is done by the McFadden Rsquared test. Then hypothesis testing uses the $\mathrm{z}$ test for each variable and the LR test for the variable as a whole.

\subsection{Theoretical foundation}

\subsubsection{Initial public offering (IPO)}

Corporate action by conducting an IPO (Initial Public Offering) conducted by the company becomes interesting for investors. This is due to the phenomenon of obtaining a substantial initial return.

Companies that will conduct an IPO must issue a prospectus, which presents information about the company, the latest and historical financial statements, profit projections, and promised dividend percentages, comparative analysis with similar industries, and the intended use of funds [11]. This stock return indicates that the prospectus' information gives a signal to the stock return on the primary market.

The results of research that show the phenomenon of underpricing in IPOs have been carried out by several researchers such as [37], the results of his research indicated that underpricing in IPOs occurs when the value was greater than 0 , indicating that investors got abnormal returns or in other words underpricing occurred. Likewise, [38] research stated that the underpricing of IPO depends on a company's period in choosing the right time when going public. Then research [39-44] showed the results that the phenomenon of underpricing occurred in all companies that conducted IPOs in various countries but the factors that influenced it was different for each study. Reference [45,46] [38], [41] showed that underpricing occurred in all countries in companies that conduct IPOs. There was an underpricing of $15 \%$ in Indonesia when the shares were first traded on almost all of the issuance of initial shares during 1989-1994 on the Jakarta Stock Exchange [47]. Likewise, research on the phenomenon of overpricing after an IPO was conducted by $[48,49]$ showed that an IPO occurred overpricing at the equilibrium point at the expected price in the secondary market. Also, an IPO study in which prices were fixed so that investors did not get a return was found by [50] and [51]. Thus the theoretical underpricing phenomenon was not always proven because, in reality, there were IPO issuers whose shares have experienced underpricing, overpricing and even an initial return of zero. Thus, an IPO event's existence will be positively responded to by investors to benefit from investment in shares in the primary market.

\subsubsection{Debt to equity ratio}

DER is a leverage ratio measured by comparing total liabilities with total equity owned by a company. DER shows the risk level of a company. The higher the DER level, the higher the risk of a company, which means the higher the uncertainty factor, so that it negatively affects the initial return. [16]. The level of leverage shows the company's ability to pay its obligations with its capital [52]. Companies with a high level of DER will be more likely to use the proceeds from their IPO to repay loans rather than for investment activities.

\subsubsection{Earning per share}

Revenue per share shows the company's ability to provide income on each common stock [52]. This ratio helps prospective investors and shareholders to measure the company's ability to generate cash flow in the future because a large EPS is an indicator of the issuer's financial performance. The high EPS ratio indicates that the company's profit is getting bigger, assuming that the outstanding shares are fixed. This shows that the greater the company gets EPS, the possibility that the company pays dividends is also greater, or if the profits are reinvested in retained earnings, it is expected to obtain greater income in the future. High profitability will reduce investor uncertainty in investing in IPO shares, thereby reducing the level of underpricing [10]. Thus the greater the EPS, the less the level of underpricing.

\subsubsection{Reputasi underwriter}

When conducting a public offering, potential investors cannot fully distinguish between good and bad quality companies. To that end, companies and underwriters give a positive signal to the market to show the company's quality at the time of the IPO. The underwriter's reputation can be used as a signal to reduce the level of uncertainty that cannot be disclosed by the information contained in the prospectus and to signal that private information from the issuer regarding the company's prospects is not misleading. Research conducted by [53] underwriter reputation is a dummy variable measured by giving a scale of 1 to the underwriters included in the top 5 underwriters based on the number of guaranteed shares and scale 0 for underwriters not included in the top 5 underwriters. The research conducted by [53] on the Australian capital market showed that the underwriter's reputation had a significant positive effect on underpricing.

In contrast to Indonesia, the research results by [34] showed that underwriters' reputation did not significantly influence underpricing with a positive coefficient direction. The underwriter reputation is a dummy variable measured by giving a scale of 1 for companies that are in the top 10 in the 20 most active brokerage house monthly JSX based on the total trading frequency and a scale of 0 for underwriters who do not enter the top 10. Thus, the more underwriter reputation will be, the level of underpricing will be even higher. 


\subsubsection{Interest rate}

Interest rates are income earned by someone who has excess funds or surplus spending units to be used temporarily by someone who needs and uses these funds to cover their deficits or deficit spending units. Interest rates are one of the monetary indicators that have an impact on economic activity. Interest rates will influence the decision to make investments that will affect the growth rate. The interest rate will also affect the capital owner's decision-making whether to invest in real assets or financial assets [54]. The interest rate set by a financial institution refers to the $\mathrm{BI}$ rate set by Bank Indonesia. The $\mathrm{BI}$ rate is a policy interest rate that reflects the monetary policy stance set by Bank Indonesia and is announced to the public [55].

\subsubsection{Abnormal return}

Abnormal return is the advantage of returns that occur against normal returns. Normal return is the expected return (return expected by investors). Thus the abnormal return is the difference between the actual return that occurs with the expected return. Returns are actual returns that occur at the $\mathrm{t}$-time, which is the difference in the current price relative to the previous price, while the expected return is a return that must be estimated. Abnormal returns are generally the focus in studies that observe price reactions or market efficiency [35]..

Abnormal return is formed because of a market reaction to an event that enters the market. An IPO event is an event that can provide an abnormal return for an investor. To calculate the abnormal return per share during the observation period using the following equation (2):

$$
A R_{i, t}=R_{i, t}-E\left(R_{i, t}\right)
$$

- $\mathrm{ARi}, \mathrm{t}=$ Abnormal stock returns $\mathrm{i}$ in period $\mathrm{t}$

- $\mathrm{Ri}, \mathrm{t}=$ The actual return that occurs for stock $\mathrm{i}$ in period $t$

- $\mathrm{E}(\mathrm{Ri}, \mathrm{t})=$ Expected level of stock returns in period $\mathrm{t}$

\section{Initial return saham}

Initial returns received by investors can be either positive or negative. Investors' expectations, of course, receive a positive initial return, which is called underpricing. Some investors believe that every IPO on the sale of the first day of the transaction will always experience a minimum profit of 5\% [56]. Reference [41] conducted a study using sample data from 1985 to 1997 obtained an average mean of initial returns of $13.9 \%$ with an average mean of companies conducting an IPO of $29.4 \%$ per month during the sample period that research. According to [57], the factors that influence stock returns consist of:
1. Macro factors are factors outside the company, namely:

- Macroeconomic factors include domestic general interest rates, inflation rates, foreign exchange rates, and international economic conditions.

- Non-economic factors include domestic political events, foreign political events, wars, mass demonstrations, and environmental causes

2. Micro factors are factors that are within the company itself, namely:

- Net income per share

- Book value per share

- Debt to equity ratio

\section{Framework}

Financial and non-financial information at the time the IPO was submitted through the prospectus. Financial information can be seen from the level of DER and EPS that have been achieved. In comparison, the non-financial information used in this research is the reputation of the underwriter. Besides, macroeconomic conditions will determine the right time for an IPO company and investors to invest.

\section{a) The effect of DER on initial return}

A company's DER level can indicate a company's risk level. Therefore, investors will consider DER when investing because a high DER causes the underpricing level when the IPO will be higher. Thus DER influences the level of underpricing. Research conducted by $[11,12]$ that DER had a positive and significant effect. While the results of the study by [58] that DER had a negative effect. Then according [13] that DER had a significant effect. Based on these results, the hypotheses drawn up are:

H1: There is an effect of DER on the initial return

\section{b) The effect of EPS on intial return}

Earnings per Share (EPS) is the income per share, which is the shareholders' right to profit. The higher the level of EPS, the greater the income that will be received by shareholders. The number of EPS can attract investors to invest in IPO company shares so that stock prices will rise to cause stock returns to increase. This is supported by the results of research by [32] and [58] that EPS had a negative effect. Then the results of [10] that EPS had a significant effect and [59] research had positively influenced stock returns. Based on these results, the hypotheses drawn up are:

$\mathrm{H} 2$ : There is an effect of EPS on the initial return.

\section{c) The effect on underwriter reputation on initial return}

The company can also cause stock returns received by investors when the IPO is looking for potential investors 
using reputable underwriters. The underwriter serves as a certifier that the company has an excellent performance to reduce the risk of IPO implementation, namely the risk of shares offered not sold, causing the stock price to decline after the IPO. This will harm investors who invest in company shares. Companies that use reputable underwriters are considered to have good quality companies. This is supported by the results of $[28,60]$ research, that the underwriter's reputation negatively influenced company value. [12] had a positive effect on stock returns. Then, $[13,11]$ researched that underwriter reputation had significantly influenced stock returns. Based on these results, the hypotheses drawn up are:

H3: There is an effect of underwriter reputation on the initial return.

\section{d) The effect of interest retes on initial return}

Investors consider macroeconomic fundamentals in investing and companies in implementing IPOs because economic conditions can determine whether capital market conditions are bullish or bearish. When economic conditions are rising interest rates, investors will divert investments from stocks to deposits. This will cause the underwriters of companies that conduct IPOs in conditions of high-interest rates will have difficulty finding potential investors, so the offered shares are not sold. This condition causes the stock price to decline from its initial price so that investors will get a negative stock return. The results of research support this by [6163] that interest rates had a positive effect on stock returns. While $[58,59,64]$ and stated that interest rates significantly influenced stock returns. Interest rates can strengthen the relationship between DER, EPS variables, and underwriter reputation on initial return. This is because interest rates are an indicator of the economic situation, which can be shown by the large interest rates on investment banking instruments so that when interest rates are high, investors can move their investments in banking instruments or bonds that provide fixed income. Based on these results, the hypotheses drawn up are:

H4: There is an effect of DER, EPS, underwriter reputation on initial return, which is moderated by the interest rate.

\section{RESULT AND DISCUSSION}

\subsection{Result}

The DER for companies that conduct IPOs from 2007 to 2017 has a DER of less than $100 \%$. This means that the number of loans used to fund an investment decision of a company is still reasonable, so that the financial risk for companies that conduct IPOs in that period is relatively small. The average DER level of companies that conduct IPOs is $56.20 \%$. Companies that do IPOs and have a DER level below the average of $46 \%$ and the remaining 54\% have a greater DER level than the average. The highest DER is DEWA company with a DER level of $94.90 \%$. The company is engaged in mining contracting services, general mining services, maintenance, and equipment maintenance. Companies in the field of mining contractors require considerable investment in heavy equipment, so it is not surprising that the DER level is relatively high. Then the average EPS for companies conducting IPOs during this period amounted to Rp.23,628. IPO companies with EPS are smaller than the average of $62 \%$, and the rest above the average is $38 \%$. Companies that have the highest EPS are TOWR of Rp.89. The company is included in infrastructure, utilities, and transportation sectors with the main areas of property development, management, and investment, which include township development, company components, development of multipurpose buildings, tourism, and industrial complexes. Companies in this sector experienced very rapid development, so TOWR produced the highest level of EPS. Furthermore, companies that do IPOs use underwriters who have a reputation of $48 \%$, and the remaining $52 \%$ use underwriters who are not reputable. Underwriter reputation is seen from the rank of ten underwriters who can obtain the highest level of stock sales.

The initial return rate for IPO companies in 2007 2017 has an initial level of return that varies. There are $75 \%$ of the IPO share price experiencing underpricing, $14 \%$ experiencing overpricing, and $6 \%$ getting a return of 0 . When referring to the theory described above, it turns out that the IPO phenomenon in the form of underpricing occurred in this period. Many investors get positive returns that invest in this period. This can be seen from the percentage of IPO shares that experience underpricing is the highest. This condition is certainly not independent of the economic situation with a relatively stable SBI interest rate indicator.

To examine the DER's effect, the EPS and the underwriter reputation on the initial return by moderating variable of interest rate is done using logit regression analysis. Before logit regression, testing must meet several assumptions so that the results are not biased. Some classical assumption test results are shown in the following Table 2:

Table 2. Result of Classical Data and Assumption Normality Tests

\begin{tabular}{|l|l|l|}
\hline \multicolumn{1}{|c|}{ Testing } & \multicolumn{1}{|c|}{ Test result } & \multicolumn{1}{c|}{ Conclusion } \\
\hline Normality test & $\begin{array}{l}\text { uji Jarque-Bera : } \\
0,2701>0,05\end{array}$ & $\begin{array}{l}\text { Normal } \\
\text { distribution }\end{array}$ \\
\hline $\begin{array}{l}\text { Multicollinearity } \\
\text { test }\end{array}$ & $\begin{array}{l}\text { Pairwaise } \\
\text { Correlation }>0.8\end{array}$ & $\begin{array}{l}\text { There is no } \\
\text { multicollinearity }\end{array}$ \\
\hline $\begin{array}{l}\text { Heteroscedasticity } \\
\text { test }\end{array}$ & $\begin{array}{l}\text { Prob } \\
\text { Obs*R_squared } \\
(0,2493>0,05)\end{array}$ & $\begin{array}{l}\text { There is no } \\
\text { heteroscedasticity. }\end{array}$ \\
\hline $\begin{array}{l}\text { Autocorrelation } \\
\text { test }\end{array}$ & $\begin{array}{l}\text { Prob } \\
\text { Obs*R_squared } \\
(0,0670>0,05)\end{array}$ & $\begin{array}{l}\text { There is no } \\
\text { heteroscedasticity. }\end{array}$ \\
\hline
\end{tabular}


The classic assumption test shows that the data already meet the classical assumptions so that it can proceed at the logit regression analysis stage. To see the likelihood ratio model's suitability and for the interpretation of the results, the Odd Ratio is used. After calculating, the following calculation results are obtained by Table 3:

Table 3. Logit Regression Data Processing Result

\begin{tabular}{|l|l|l|}
\hline \multicolumn{2}{|c|}{ Coefficient Variable } & Odds Ratio \\
\hline C & -30.66185 & 0.99 \\
\hline DER & 14.72152 & 1.00 \\
\hline EPS & 6.018034 & 1.00 \\
\hline Rep_Under & -0.587485 & 1.00 \\
\hline Interest Rate (SB) & 407.4890 & 1.00 \\
\hline DER* SB & -168.6148 & 0.99 \\
\hline EPS* SB & -74.82382 & 0.99 \\
\hline Rep_Under*SB & 11.02296 & 1.00 \\
\hline McFadden R-squared & 0.314976 & \\
\hline LR statistic (7 df) & 55.44260 & \\
\hline Prob (LR statistic) & 0.000000 & \\
\hline N = 209 & & \\
\hline Sig = 0.05 & & \\
\hline
\end{tabular}

Source : data processed

From the table above, the regression model can be arranged by equation (3) as follows:

$$
\begin{gathered}
\ln \left(\frac{\hat{\mathrm{p}}}{1-\hat{\mathrm{p}}}\right) D I R_{i}=-30.66185+14.72152 D E R_{i}+ \\
6.018034 E P S-0.587485 \operatorname{Rep}_{-} \text {Under }_{i}+407.4890 S B_{i}- \\
168.6148 D E R_{i} * S B-74.82382 E P S_{i} * S B+ \\
1102296 \text { Rep_Under }_{i} * S B+u_{1}(3)
\end{gathered}
$$

Based on the logit regression equation, it can be analyzed that the DER variable has an odds ratio value of 1 , which means that for each increase in one unit DER, the initial return increases by 1 unit. Then, for EPS variables, the odds ratio is 1 . This means that every increase in EPS is one unit, then the initial return will increase by 1 unit. Furthermore, for the Underwriter Reputation variable, the odds ratio is 1 . This means that the more underwriters, the initial return will decrease by 1 unit. As for the interest rate variable (SB), the odds ratio is 1. This means that for each SB increases in one unit, the initial return will increase by 1 unit. Likewise, for the DER variable, which is moderated by the interest rate (DER* SB), the odds ratio is 0.99. This means that each increase in DER * SB is one unit, then the initial return will decrease by 0.99 units. Then for EPS variables moderated by the interest rate (EPS * SB), the odds ratio is 0.99 . With each increase in one unit EPS $* \mathrm{SB}$, the initial return will decrease by 0.99 units. Furthermore, for the Underwriter Reputation variable, which is moderated by the interest rate (Under * SB), the odds ratio is 1 . This means that the more Under Under SB is, the initial return will increase by 1 unit.

Furthermore, the results of testing the magnitude of the contribution of DER, EPS, and underwriter reputation, which are moderated by the interest rate, obtained McFadden R-squared value of 0.314976. This shows that the DER, EPS, and underwriter reputation moderated by the interest rate can explain the initial return variable by $31.4976 \%$, while the remaining $68.5024 \%$ is explained by other factors included in the model. To determine the significance of the influence of DER, EPS, and underwriter reputation, which is moderated by the interest rate, the $\mathrm{Z}$ test is used with twoway testing at a significance level of $5 \%$, with criteria if the p-value is $<5 \%$, then $\mathrm{H} 0$ is rejected and p-value $>5 \%$ $\mathrm{H} 0$ is accepted. The test results show that the statistical LR value is 55.44260 with a Prob (LR statistic) value of 0.0000 . Thus, H0 is rejected, meaning that there is an influence between DER, EPS, and underwriter reputation, moderated by the interest rate on initial return. Alternatively, in other words, the logit regression models can be said to be good. Then to test the significance of

\begin{tabular}{|c|c|c|c|c|}
\hline Variable & $\begin{array}{c}\text { Coefficien } \\
t\end{array}$ & $\begin{array}{l}\text { Std. } \\
\text { Error }\end{array}$ & $\begin{array}{c}\text { z- } \\
\text { Statistic }\end{array}$ & Prob. \\
\hline $\mathrm{C}$ & -30.66185 & $\begin{array}{l}10.3858 \\
3\end{array}$ & $\begin{array}{l}- \\
2.95227 \\
8\end{array}$ & 0.0032 \\
\hline DER & 14.72152 & $\begin{array}{l}9.33836 \\
4\end{array}$ & $\begin{array}{l}1.57645 \\
6\end{array}$ & 0.1149 \\
\hline EPS & 6.018034 & $\begin{array}{l}2.97083 \\
1\end{array}$ & $\begin{array}{l}2.02570 \\
7\end{array}$ & 0.0428 \\
\hline Rep_Under & -0.587485 & $\begin{array}{l}4.43055 \\
1\end{array}$ & $\begin{array}{l}- \\
0.13259 \\
9\end{array}$ & 0.8945 \\
\hline $\begin{array}{ll}\begin{array}{l}\text { Interest } \\
\text { (SB) }\end{array} & \\
\end{array}$ & 407.4890 & $\begin{array}{l}148.918 \\
3\end{array}$ & $\begin{array}{l}2.73632 \\
5\end{array}$ & 0.0062 \\
\hline $\mathrm{DER} * \mathrm{SB}$ & -168.6148 & $\begin{array}{l}139.444 \\
4\end{array}$ & $\begin{array}{l}- \\
1.20919 \\
0\end{array}$ & 0.2266 \\
\hline EPS*SB & -74.82382 & $\begin{array}{l}42.7742 \\
3\end{array}$ & $\begin{array}{l}- \\
1.74927 \\
3\end{array}$ & 0.0802 \\
\hline $\begin{array}{l}\text { Rep_Under*S } \\
\text { B }\end{array}$ & 11.02296 & $\begin{array}{l}67.9341 \\
3\end{array}$ & $\begin{array}{l}0.16225 \\
9\end{array}$ & 0.8711 \\
\hline
\end{tabular}
each independent variable is shown in the Table 4 as follows:

Table 4. Z TEST RESULT

Source: data processed

The data processing results for each variable shows that for the DER variable, the p-value is $0.1149>0.05$, then $\mathrm{HO}$ is accepted, meaning that the DER has no significant effect on the initial return. Then for EPS pvalue value of $0.0428<0.05, \mathrm{H} 0$ is rejected, meaning that EPS has a significant effect on initial return. Furthermore, the reputation of the underwriter p-value is $0.8945>0.05$ and or 0.1 , then $\mathrm{H} 0$ is rejected, meaning that the reputation of the underwriter does not significantly influence the initial return. For the interest rate (SB) pvalue is $0.0062<0.05$, then $\mathrm{H} 0$ is rejected, meaning the interest rate $(\mathrm{SB})$ has a significant effect on initial return. Whereas for the independent variable, which is moderated by the interest rate (SB), the result is that $\mathrm{DER}^{*} \mathrm{SB}$, the p-value is $0.2266>0.05$ and or 0.1 , then $\mathrm{H} 0$ is accepted. It means that DER* SB has no significant effect on initial return, but for EPS variable* $\mathrm{SB}$, the $\mathrm{p}$ value value is $0.0802<0.1$, then $\mathrm{H} 0$ is rejected, meaning that EPS * SB has a significant effect on initial return. 
Then, the reputation variable * SB Underwriter, $\mathrm{p}$-value value of $0.8711>0.05$ and or 0.1 then $\mathrm{H} 0$ has accepted means that Rep_Under* SB has no significant effect on initial return.

\subsection{Discussion}

Based on the results of testing the hypothesis, it concluded that there is an influence between DER, EPS, and underwriter reputation, which is moderated by the interest rate on the initial return or, in other words, the logit regression model can be said to be good. This means that the issuer's information when conducting an IPO is essential information for investors in considering the investment decision on IPO shares. According to [11], investor perceptions are based on investors 'assessment of the performance shown in the initial prospectus, where the prospectus is one of the main sources of information used by investors to decide whether to invest in the shares of the issuer or other issuers' shares. Investors' reaction to this critical information will cause a stock price reaction because the company's vital information at the prospectus indicates the formation of prices because of important information. This is in line with the market microstructure theory that focuses on the process of price formation because of new information (Mardhavan, 2000).

Some studies that measure the effect of prospectus information on stock returns are [10,11,58,65,66], separating variables research between non-financial information and financial information. Some information that concerns investors is the DER level. DER level shows the level of financial risk of a company. Other information is EPS which shows the company's ability to generate income for shareholders. Another essential piece of information is the reputation of the company's underwriter when conducting an IPO. Investors consider underwriters as certifiers of share prices of issuers to have information, so when a company submits information, it will be responded to by the market as a signal of certain events that can affect the company's value [8]. Besides the information submitted on the company's prospectus, external information that investors consider is the interest rate. The interest rate is one of the macroeconomic indicators, which can show the economic conditions that occur when determining the direction of the investment for investors.

Based on the results of testing each variable's hypotheses, the DER does not significantly influence the initial return. This study is in line with [14] research that the DER level did not influence initial return. Likewise, with [67] research, DER has no significant effect on initial returns for non-financial companies. This is because investors can judge that the high level of DER in a company is used to fund profitable investment decisions so that even though the risk level of a company is high, the company's income and growth is high so that the company will be able to generate greater income for the welfare of shareholders. . While EPS shows a significant effect on the initial return. This study's results are in line with the study of [59] which states that EPS has a significant effect and the results of the study have a positive effect on stock returns. Likewise with [10,12,58] that EPS has a significant effect on initial return. This shows that EPS is important information for investors because the higher the EPS, the greater the income received by shareholders. Although it is possible for a company to not share its entire income with shareholders, high EPS can also be used as an internal source of funds that will be used to fund profitable investment opportunities for the company. Thus, the magnitude of EPS can attract investors to invest in IPO company shares so that stock prices will rise to cause stock returns to increase. Then the underwriter's reputation has no significant effect on the initial return. This is in line with [34] research that the underwriter's reputation has no significant effect. Although the underwriter is the party who can certify the level of return that investors will receive, many investors invest without considering the information contained in the prospectus. This is consistent with [3] study, which states that accounting information or information contained in the prospectus is not useful in making decisions because the information signal in the prospectus cannot make investors changes to previously held beliefs. According to [68], traders generally invest only in stock prices, no matter what the stock is. This condition is caused by investors in Indonesia who are believed to have not made the most of the published financial information in their investment decision-making because it is believed that most Indonesian investors are speculators who have more funds without investment knowledge and skills [2].

Furthermore, the interest rate (SB) significantly influences the initial return. The results of research support this by $[58,59,64]$ that interest rates significantly influence stock returns. Once the results of research by $[61-, 63]$ show that interest rates have a positive effect on stock returns. The interest rate becomes a reference for investors in investing. When economic conditions are experiencing sluggish, investors prefer to invest in fixed income investment products such as bonds or banking products because it will provide a higher level of income certainty than investing in stocks. Therefore, the interest rate will be a consideration factor for investors in choosing investment alternatives offered to investors.

For the independent variable moderated by the interest rate $(\mathrm{SB})$, the results show that DER * SB and Underwriter * SB reputation had no significant effect on initial return, but for EPS * SB variable had a significant effect on initial return. This means that the interest rate could moderate the relationship of the EPS level to the initial return. However, for the DER level and the underwriter's reputation, the interest rate was not able to moderate the relationship between the two to the initial 
return because the DER level and the underwriter reputation both had moderation variables. No such variables did not have a significant effect on initial return. This can be due to EPS information for investors that can be considered more than other factors because profitable companies could manage their assets to generate income for their shareholders. Besides that, there is experience from investors in investing, so the factors considered are getting smaller. This is in line with [69] research, which stated that the longer an investor invested, the less or fewer factors were considered because, the longer, the more experience so that more investment decisions were based on experience alone. With this investor behavior, it will impact other investors who go along (herding behavior) without doing a fundamental analysis of the shares to be purchased. Before buying shares, investors conduct social interaction with brokers or other investors relating to the exchange transactions. This interaction can affect investors' decisions in making transactions [1]. Investors can be influenced to buy or sell shares or even follow what other investors are doing.

\section{CONCLUSION}

Some vital information that is of interest to investors at the time of the IPO is the DER level, EPS, underwriter reputation, and macroeconomic factors as measured by the interest rate. In the event of an IPO, investors expect the condition of the share price to be underpricing. The higher the level of underpricing, the higher the return that will be received by investors.

The results of statistical tests show that the level of DER, EPS, and underwriter reputation moderated by interest rates significantly influences the initial return. This means that the issuer's information when conducting an IPO is important information for investors in considering investment decisions on IPO shares. The results of testing each variable's hypotheses indicate that DER has no significant effect on the initial return. In comparison, EPS has a significant effect on the initial return. Then the underwriter's reputation has no significant effect on the initial return.

Furthermore, the interest rate (SB) significantly influences the initial return. The interest rate becomes a reference for investors in investing. When economic conditions are experiencing sluggish, investors prefer to invest in fixed income investment products such as bonds or banking products because it will provide a higher level of income certainty than investing in stocks. Therefore, the interest rate will strengthen or weaken the relationship between the independent and dependent variables. The results of testing the DER level are moderated by the interest rate (SB) obtained. The results showed that the DER * SB and Underwriter * SB reputation did not significantly affect the initial return, but for the EPS * SB variable significantly influenced the initial return. This means that the interest rate can moderate the relationship of the EPS level to the initial return, but for the DER level and the reputation of the underwriter the interest rate is not able to moderate the relationship between the two to the initial return because the DER level and the underwriter reputation both for moderation and without the variable are the same had a significant effect on initial return.

The implication of the study:

\section{For Investors}

Investors in investing in IPO shares can consider EPS information as measured by EPS and macroeconomic factors, especially the interest rate because the research results show both of these variables have a significant influence.

\section{For Issuers}

For issuers conducting IPOs, EPS information and interest rates is information that investors consider in investing. Therefore, the company must be able to efficiently carry out its operations so that the company earns a high profit. Besides that, issuers must also consider macroeconomic factors, especially in determining the most appropriate time to conduct an IPO so that the shares offered to the public can be sold so that the share price of the issuer increases.

\section{Limitation of the study:}

This study's results can be developed by adding variables that can affect initial returns, such as liquidity ratios, ownership structure, capital market situation, type of industry, and international economic conditions. According to [57], these variables are expected to affect stock returns. In addition, researchers can further consider technology-based industries as an analysis unit with a more extended period both for research samples and measurement of initial return cointegration with long-term returns.

\section{REFERENCES}

[1] J.R. Nofsinger, Psychology of investing, 2Ed. New Jersey: Precentice - Hall Inc, 2005.

[2] C.M. Haryanto, "Pengaruh relevansi laba akuntansi terhadap return saham dengan risiko perusahaan dan leverage sebagai variabel pemoderasi pada perusahaan manufaktur di BEI," J. Ilmiah Manahasiswa Akuntansi., vol. 1, no. 1, 2012.

[3] D. Septyanto, "Faktor-faktor yang mempengaruhi investor individu dalam pengambilan keputusan investasi sekuritas di Bursa Efek Indonesia (BEI)," J.Ekonomi., vol. 4, no. 2, 2013. 
[4] E.F. Brigham, and J.F. Houston. Fundamentals of financial management, $14^{\text {th }}$ Ed. Mason: SouthWestern Cengange Learning, 1986.

[5] Arti Debt-to-Equity Ratio (DER) dan Urgensinya dalam Analisa Saham. Investasi Online. January 3, 2019. [Online]. Avaible: https://investasi.online/artidebt-to-equity-ratio-der-dan-urgensinya-dalamanalisa-saham/.

[6] Apa itu analisa fundamental. HDX.id. 2020. [Online]. Avaible: http://hdx.co.id/index.php/content/detail/38/Apaitu-analisa-fundamental.

[7] Mencermati peran strategis penjamin emisi. EKEFinance. November, 10. [Online]. Avaible: https://economy.okezone.com/read/2010/11/10/226/ 391690/mencermati-peran-strategis-penjaminemisi.

[8] S.H. Teoh, I. Welch, and T.J. Wong, "Earning management and the long run market performance of initial public offerings," J. of Finance, vol.53, pp. 1935-1974, 1998.

[9] Berharap Bunga Acuan BI Turun, Ini Strategi Investasi Saham. CNCB Indonesia. July 08, 2019. [Online] Avaible: https://www.cnbcindonesia.com/market/201907081 83000-17-83478/berharap-bunga-acuan-bi-turunini-strategi-investasi-saham.

[10]M. Ardiansyah, “ Pengaruh variable keuangan terhadap return awal dan return 15 hari setelah IPO serta moderasi besaran perusahaan terhadap hubungan antara variable keuangan dengan return awal dan return 15 hari setelah IPO di Bursa Efek Jakarta," J. Riset Akuntansi Indonesia., vol. 7, no. 2, pp. 123-153, 2004.

[11]R. Trisnawati, "Pengaruh informasi prospectus terhadap return saham di Pasar Perdana," Simposium Nasional Akuntansi IX., 2007.

[12] J.B. Kim, Krinsky and Lee, "Motive for going public and underpricing : new findings from Korea. J. of Business Finance \& Accounting., vol. 20, no. 2, 1993.

[13]Daljono, “Analisis faktor-faktor yang mempengaruhi return saham yang listing di BEJ tahun 1990-1997," Proceeding Simposium National Akuntansi III., 2000.

[14]E.K. Putra, Y. Seosettio, and T. Wijiyanti, "Pengaruh kinerja keuangan perusahaan terhadap pembentukan initial return ( studi pada perusahaan yang melakukan initial public offering ( IPO ) di Bursa Efek Indonesia Periode Tahun 2011-2015 ). J. Ekonomi Bisnis., vol. 2, pp. 179-189, 2016.
[15] Ratnasari, and G. Hudiwinarsih. "Analisis pengaruh informasi keuangan, non keuangan serta ekonomi makro terhadap underpricing pada perusahaan ketika IPO. J. Buletin Studi Ekonomi, vol. 18 no. 2, 2013.

[16] Wijayanto, “Analisis Faktor-Faktor yang Mempengaruhi Underpricing Saham Saat IPO di BEI," Accounting Analysis Journal., vol. 2, no. 4, pp. 386-394, 2010.

[17] L.S. Wikjaksono, “Analisis faktor-faktor keuangan yang mempengaruhi fenomena underpricing pada perusahaan sektor keuangan yang terdaftar di Bursa Efek Indonesia 2002-2010," Berkal Ilmiah Mahasiswa Akuntansi., vol. 1 no. 1, 2012.

[18] Wahyusari, “Analisis faktor-faktor yang mempengaruhi underpricing saham saat IPO di BEI," Accounting Analysis J., vol. 2, no. 4, pp. 386394, 2013.

[19]E. Retnowati, "Penyebab underpricing pada penawaran saham perdana di Indonesia. Accounting Analysis J., vol. 2, no. 2, pp. 182-190, 2013.

[20] Emilia. L. Sulaiman. R. Sembel, "Faktor-faktor yang mempengaruhi initial return 1 hari, return 1 bulan, dan pengaruh terhadap return 1 tahun setelah IPO. J. of Applied Financing and Accounting., vol. 1, pp. 116-140, 2008.

[21]L. Prawesti, and A. Indrasari. "Informasi Akuntansi dan Non Akuntansi terhadap Initial Return Saham," J. Akuntansi dan Investasi., vol. 15, no. 1, 2014.

[22] Luftianto, "Determinan Initial Return Saham Go Public Tahun 2006-2011., J. Ilmu Manajemen., vol. 1, no.1, 2013.

[23] S. Hermuningsih, "Pengaruh rasio keuangan terhadap initial return saham setelah initial public offerings (IPO) pada perusahaan publik di Indonesia," J. Universitas Paramadina., vol. 11, no 3, 2014.

[24] I.Gd.N.H. Wiguna, and K. Yadnyana, "Analisis faktor-faktor yang mempengaruhi initial return pada penawaran saham perdana," e-J. Ekonomi dan Bisnis Universitas Udayana., vol. 4, no. 12, pp. 921-946, 2015.

[25]F. Sardju, "pengaruh informasi akuntansi dan non akuntansi terhadap initial return dan return saham 30 hari setelah IPO," J. Ilmiah Akuntansi dan Humanika., JINAH,vol. 4, no. 1, 2014.

[26] Narsiwan, "Reputasi penjamin emisi, return awal, return 15 hari sesudah IPO dan kinerja perusahaan satu tahun sesudah IPO di BEJ," Simposium Nasional Akuntansi III., pp. 573-591, 2000. 
[27] Su, and K. Bangassa, "The impact of underwriter reputation on Initial Returns and long-run performance of Chinese IPOs," J. of International Financial Markets, Institutions, and Money., vol. 21, no. 5, pp. 760-79, 2011.

[28] R.P. Beatty, "Note: auditor reputation and the pricing of initial public offerings," The Accounting Review., vol. 44, no. 4, pp. 693-709, 1989.

[29] Chua, "Market conditions, underwriter reputation, and first day return of IPOs," J.1 of Financial Markets, Elsevier., pp. 131-152, 2014.

[30] Prawesti, Linggar \& Arum Indrasari, "Informasi akuntansi dan non akuntansi terhadap initial return saham," J. Akuntansi dan Investasi., vol. 15, no. 1, 2014.

[31] Gautama, L. Diayudha, V.A. Puspitasari, “ Analisa faktor-faktor yang mempengaruhi initial return setelah initial public offering (IPO)," J. Administrasi dan Kantor., vol. 3, no. 2, 2015.

[32] J-B. Kim, I. Krinsky, and L. Jason, "The role of financial variable in the pricing of Korean IPO," Pacific Business Finance J., 1995.

[33] U. Sekaran, and R. Bougie, Research methods for business. The United Kingdom: John Wiley \& Sons. Ltd, 2013.

[34] Yolana, and D. Martani, "Variabel-variabel yang mempengaruhi fenomena underpricing pada penawaran saham perdana di bej tahun 1994-2001," Makalah Seminar Nasional Akuntansi VIII., 2005.

[35] H. Jogiyanto, H, Teori portofolio dan analisis investasi. Yogyakarta: BPFE, 2010.

[36] Sunariyah, Pengantar pengetahuan pasar modal. Yogyakarta: UPP STIM YKPN, 2011.

[37] R. Ibbotson, R. "Price performance of common stock new issues. J. of Financial Economics., vol. 2, pp. $235-272,1975$.

[38] J.R. Ritter, "The hot issue market of 1980," J. of Business., vol. 57, no. 2, pp. 215-240, 1984.

[39] S.M. Dawson, "Initial public offering underpricing: the issuer's view - a note. J. of Finance., vol. 42, pp. 159-162, 1987.

[40] O. Yong, "Who actually did gain from the underpricing of IPOs," Capital Markets Review., vol. 4 no. 1, pp. 33-47, 1996.

[41] M. Lowry, and G.W. Schwert, "The variability of ipo initial returns. working paper," University of Southern California, Los Angeles, CA 90089, 2002.
[42] M.K.N. Taufil, "The long-run performance of initial public offering in Malaysia," The MFA 9th Conference, 12-13th June, Kuala Lumpur., 2007.

[43] Martini, L.L. Sinaga, and A. Syahroza, A. "Analysis on factors affecting ipo underpricing and their effects on earnings persistence," World Review of Business Research., vol. 2, no. 2, pp. 1-15, 2012.

[44] J. Zhou, and L.J. Lao, L.J. "Analysis of influencing factors of IPO underpricing in ChiNext," Physics Procedia., vol. 33, pp. 846-851, 2012.

[45]M. Yeap, "An empirical investigation into the underpricing of ipos in the new millennium in Malaysia," M.S. thesis. Nottingham Trent University, UK, 2006.

[46] Y. Loughran, and J.R. Ritter, "uniformly least powerful test of market efficiency. J. of Financial Economics., vol. 55, pp. 413-444, 2000.

[47] M. Hanafi, M. "Efisiensi Emisi saham baru di Bursa Efek Jakarta (1989-1994)," Kelola UGMYogjakarta., vol. 17, pp. 88-105, 1997.

[48] A.K. Purnandanam, and B. Swaminatahan, "Are IPOs really underpriced?," Review of Financial Studies., vol. 17, no. 3, pp. 811-848, 2004.

[49] T. Leite., "Excess initial returns in IPOs," J. of Financial Intermediation., vol. 13, pp. 359-377, 2004.

[50] J.W.III. Peavy, "Returns on initial public offerings of closed-end funds," Review of Financial Studies., vol. 3, pp. 695-708, 1990.

[51]C.J. Muscarella, "Price performance of the Initial Public Offerings of Master Limited Partnerships. Financial Review, vol. 23, pp. 513-521, 1988.

[52] Rahardjo, Dasar-dasar analisis fundamental saham laporan keuangan perusahaan. Yogyakarta: Gajah Mada University Press, 2009.

[53]W. Dimovski, S. Philavanh. R. Brooks. "Underwriter reputation and underpricing: evidence from the Australian IPO market," Review of Quantitative Finance and Accounting., vol. 37 no.4, pp. 409-426, 2010.

[54]Judisseno, and K. Rimsky. Sistem moneter dan perbankan indonesia. cetakan kedua. Jakarta: Gramedia Pustaka Utama, 2005.

[55] Penjelasan BI rate sebagai suku bunga acuan. Bank Indonesia. 2020. [Online]. Avaible: http://www.bi.go.id/penjelas-bi-rate-as-suku-bungaacuan. 
[56] A.H. Manurung, Initial public offering (IPO) konsep, teori, dan proses. Jkarta: PT. Adler Manurung Press, 2013.

[57] M Samsul. Pasar modal dan manajemen portofolio. Surabaya : Erlangga, 2006.

[58] Achyani, “Analisis informasi prospectus yang berpengaruh terhadap return awal penawaran perdana di BEJ," J. Ekonomi dan Bisnis Indonesia, vol. 12, no. 2, 1999.

[59] Yoga, "Hubungan teori signaling dengan underpricing saham pada penawaran perdana (IPO) di Bursa Efek Jakarta,” Ekplanasi., vol. 5, no. 1, pp. 69-86, 2010.

[60]R. M. Balvers, and R.E. Miller.,"Underpricing of new issues and the choice of auditor as a signal of investment banker reputation," The Accounting Review., vol. 64, pp. 602-622, 1988.

[61] N. Chen, R. Roll, and S. Ross, S, "Economic forces and the stock markets," J. of Business., vol. 59, pp. 383-403, 1986.

[62] K. Rock, "Why new issues are underpriced," J. of Financial Economics., vol. 15 no. 1, pp. 187-212, 1986.

[63] G.R. Jensen, and R.R. Johnson, "An examination of stock price reaction to discount rate changes under alternative monetary policy regimes," Quarterly J. of Business and Economics., vol. 32, pp. 26-31, 1993.

[64]R. Ameer, "Macroeconomic factors and Initial Public Offering (IPOs) in Malaysia," Asian Academy of Management J. of Accounting and Finance., vol. 8, no. 1, pp. 41-67, 2012.

[65] Suyatmin, and Sujadi. "Faktor-faktor yang mempengaruhi underpriced pada penawan perdanan di Bursa Efek Jakarta., J. Manajemen dan Bisnis., vol. 10, no. 1, pp. 11-32, 2006.

[66] S. Nurhidayati, and N. Indriantoro "Analisis faktorfaktor yang berpengaruh terhadap tingkat underpriced pada penawan perdanan di BEJ," J. Bisnis dan Eonomi, vol.6, no. 2, 1998.

[67] Y. Susilowati, "Konsekuensi signal prospectus perusahaan terhadap initial return saham pada Pasar Perdana di Bursa Efek Indonesia," J. Dinamika Keuangan dan Perbankan., vol. 2 no. 1, pp. 23-37, 2010.

[68] A.P. Tambunan. Analisis saham pasar perdana. Jakarta: Elex Media Komputindo, 2013.

[69] N. Christanti, and L.A. Mahastanti, "Faktor-faktor yang dipertimbangkan investor dalam melakukan investasi," J. Manajemen Teori dan Terapan., vol. 4, no. 3, 2011. 